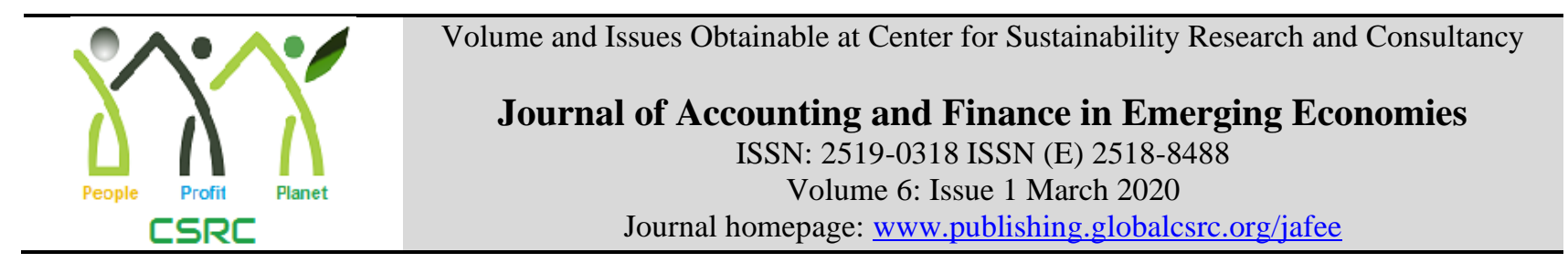

\title{
Analysis of Energy Crisis, Energy Security and Potential of Renewable Energy: Evidence from Pakistan
}

\author{
${ }^{1}$ Khalid Latif, ${ }^{2}$ Muhammad Yousaf Raza, ${ }^{3}$ Ghulam Mujtaba Chaudhary, ${ }^{4}$ Adeel Arshad \\ ${ }^{1}$ Assistant Professor, College of Commerce, Government College University Faisalabad, Faisalabad .Pakistan \\ Khalidlatif@gcuf.edu.pk \\ ${ }^{2}$ Department of Business Administration, Federal Urdu University of Arts Science and Technology Islamabad, \\ Pakistan yousafrazat@gmail.com \\ ${ }^{3}$ Assistant Professor, University of Kotli, Azad Jammu and Kashmir. ghulam.mujtaba@uokajk.edu.pk \\ ${ }^{4}$ Lecturer, Department of Business Administration, University of Kotli, Azad Jammu and Kashmir
}

\begin{tabular}{|c|c|}
\hline ARTICLE DETAILS & ABSTRACT \\
\hline $\begin{array}{l}\text { History } \\
\text { Revised format: February } 2020 \\
\text { Available Online: March } 2020\end{array}$ & $\begin{array}{l}\text { Over the last thirty years, Asian countries have become a chief player in } \\
\text { the worldwide scene. Pakistan is facing an acute energy disaster since last } \\
\text { decade that impacts on social and economic development. Sustainable } \\
\text { energy supply is an essential feature for the economic growth of any }\end{array}$ \\
\hline $\begin{array}{l}\text { Keywords } \\
\text { Energy Security, Renewable } \\
\text { Energy, Climate Change, Social- } \\
\text { Economic Development }\end{array}$ & $\begin{array}{l}\text { society. From the last five years, Pakistan is facing a shortfall between } \\
4,000-5,000 \text { megawatt. This study inspects the association between energy } \\
\text { security, energy crisis, energy demand, energy supply, and renewable } \\
\text { potential in Pakistan. It also evaluates the final energy demand-supply } \\
\text { gap, provincial renewable energy distribution, sectorial distribution, and }\end{array}$ \\
\hline $\begin{array}{l}\text { JEL Classification: } \\
P 28, Q 20, Q 54, O 12\end{array}$ & $\begin{array}{l}\text { policy recommendation for future energy. For this study, we applied } \\
\text { renewable and non-renewable energy scenarios during 2014-2035 and } \\
\text { Market-Allocation method to prove the energy situation in Pakistan. The } \\
\text { outcomes show that renewable resources are the best option in reducing } \\
\text { energy risk, import cost, and enhance environmental and economic } \\
\text { sustainability. With the objectives of our key findings, targeted } \\
\text { suggestions and policies are given. }\end{array}$ \\
\hline
\end{tabular}

(C) 2020 The authors, under a Creative Commons Attribution-Non OPEN ACCESS

Corresponding author's email address: Khalidlatif@gcuf.edu.pk

Commercial 4.0

Recommended citation: Latif, K., Raza, M. Y., Chaudhary, G. M. \& Arshad, A., (2020). Analysis of Energy Crisis, Energy Security and Potential of Renewable Energy: Evidence from Pakistan. Journal of Accounting and Finance in Emerging Economies, 6 (1), 167-182

DOI: $10.26710 /$ jbsee.v6i1.1072

\section{Introduction}

The use of electricity is increasing continuously due to the growth of the global population and industrial development. In improving thermal efficiency and independence on external fossil fuel energy sources, solar energy, a clean energy source has provided great potential. This energy is used in environmental protection, $\mathrm{CO} 2$ emissions reduction and in agriculture production. It is, therefore; due to increase in demand and consumption for energy identifies that it will create a key issue in the globe (Şen, 2004). To fulfill the requirement of vitality demand, clean power means are the best opportunities. Pakistan is facing acute energy crisis especially in the 
northern, rural and off-grid areas (Raza et al., 2019). The energy management is still fighting to contract with the power disaster because the energy hindrance exceeds 2,888 megawatts in June 2017. But, in May 2018, the shortfall touched (6000-7000 MW), and load shedding has risen to five hours (Lin and Raza, 2019a). The rising demand of Pakistan's energy sector is met by petroleum products; electricity, LPG, and coal consumption (see Fig.1). Overall, the consumption of oil is increasing during the given period. Oil consumption increased by $107.6 \%$ while gas is the second consumption competitor which has increased by 98.02\% during 2018. During 2017-2018, the energy consumption was reported as 55Mtoe which has increased by 9.7 per cent than the previous year 20162017 (HDIP, 2018). Final energy consumption during 2017-2018 with the share of different sectors i.e. industrial $(37.5 \%)$, transport $(33.9 \%)$, domestic $(21.2 \%)$, commercial $(3.6 \%)$, other Government $(2.3 \%)$, and agriculture (1.5\%) was calculated given in Fig.2, while Fig.3 illustrates that the primary energy supplies were shared by oil (31.2\%), gas (34.6\%), LNG import (8.7\%), LPG (1.2\%), coal (12.7\%), and electricity by $11.6 \%$ (HDIP, 2018). This is because of the continuous increase in the consumption of transport and industrial sector of Pakistan (see Fig.2). The usual energy shortage started in the last decade due to economic competition (Shaikh et al., 2015). Due to much consumption and shortages, energy production sectors unsuccessful to generate the expected energy units. According to the Ministry of petroleum Pakistan, import bill of oil during the year 2017-2018 reached US\$12 billion which has become a huge burden on foreign reserves. For this, the government and petroleum ministry prepared a long-term plan with the help of public-private sector for the next twenty-five years. This plan will support in improving energy security in Pakistan. Overall, the total available energy in Pakistan in 2017-2018 was 88.25Mtoe while the domestic production was 46.725Mtoe and 41.525Mtoe (HDIP, 2018). This clarifies that Pakistan is much dependent on energy imports. Although, due to the high prices of petroleum products, Pakistan is unable to consistent its economy. According to (Khalil and Zaidi, 2014), the demand for electricity in Pakistan changes on a cyclical base and especially boosts in the summer season. So, the difference between supply and demand is encountered by blackouts and lack of energy has affected the industry of Pakistan to destroy (see Fig.3). This condition has forced agriculturalists and industrialists to choose for different sources of energy creation. Pakistan is situated in the most extreme sun-powered separation territory on the earth (Firoz and Intikhab, 2004). Consequently, in lessening energy crisis and shortfall in Pakistan it is essential to widen natural power sources such as solar, wind, hydropower, and wave. Recently, hydro-energy as a clean and renewable is ensuring much less environmental pollutions and could be applied at a macro level over the future. The major advantage is that the conversion of the dominant energy in hydrogen to electricity energy could be carried-out by growing hydrogen fuel cells as an economical and sustainable electric substance for hydrogen development reaction. According to (Shi et al., 2019), hydrogen is taken as an energy transporter not as a key fuel because the transportation of hydrogen energy has become a challenge in the world. Thus, many researchers, for example, (Askari et al., 2019); (Salarizadeh et al., 2019), and (Askari and Salarizadeh, 2019a) and (Askari and Salarizadeh, 2019b)considered hydrogen energy as energy carriers in the production, storage, transfer process. Although, there are some fundamental issues in Pakistan because of limited indigenous energy resources such as renewables, hydro, coal, gas, oil and renewable energy technologies (Raza and Shah, 2019). Without environmental concerns, the financial burden on national energy import is the major problem for the country's economy. Currently, Government of Pakistan (GOP) is pursuing policies to invite foreign investors in renewable energy production (i.e. hydro, coal, wind, solar, biomass, and geothermal) in the energy sector to substitute imported energy resources (HDIP, 2018). Additionally, the contribution of each energy supply during 2018 was $31.2 \%, 34.6 \%, 8.7 \%, 1.2 \%, 12.7 \%, 7.7 \%$, $2.7 \%, 1.1 \%$, and $0.1 \%$ of oil, gas, LNG, LPG, coal, hydro, nuclear, renewable, and imported electricity. In spite of huge electricity efficiency from hydro resources, the GOP should also discover alternative energy resources such as renewables. These will not only fulfill the needs of Pakistan but also reduce pollution, imported energy, and meet the future needs of the country.

The potential for clean vitality resources can be utilized to electrify the off-grid areas of Pakistan. According to (Farooq and Kumar, 2013), the solar energy can be used as water heaters and solar cookers. For the family unit necessity, Pakistan has utilized sun based vitality at the huge level because the normal sunshine hours in Pakistan are 3000h-3000h every year and the intensity of solar index for 6-7 h for each day is received (Sadiq, 2018)(Sadiq, 2018); (Raza et al., 2019). For this, Pakistan has contracted several clean energy plans with China i.e. Quaid-iAzam solar power project of 300MW, Sachal wind power of $50 \mathrm{MW}, 50 \mathrm{MW}$ of Hydro-China Dawood, wind project of 99MW Jhimpir (Ministry of Finance, 2018). Overall, renewable primary energy balance was counted as 920,580Toe during 2017-2018 in Pakistan (HDIP, 2018). These renewable energy projects will help Pakistan in economic development, import/export, job creation and business activities (Table.2). For example, the government of Pakistan has also started work with a for-profit company providing supportable and ingenious solar products such as fans, lights, mobile chargers, television, and bulbs to micro businesses in off-grid parts of Pakistan. As a 
result, these schemes have the extraordinary potential to create financial advantages, vitality security, and diminished contamination and reduce climate change (Masud, 2009). This condition inspires us to inspect the energy crisis and renewable energy potential from Pakistan's power sector. Additionally, this research discusses the energy crisis and encourages renewable energy technologies in Pakistan. Many researchers have proved in different countries i.e. (Khare et al., 2013) for India; (Ahmed et al., 2014) for Bangladesh; (Stritih et al., 2007) for Slovenia; (Gurung et al., 2013) for Nepal; (Aliyu et al., 2015) for Ghana; (Shaikh et al., 2015) for Pakistan and (Niu et al., 2019) for China have measured the output of clean electricity and found a consensus that clean energy is one of the best ways in sustainability, energy security, cope with energy crisis and ecological degradation. According to the (German Watch, 2017), Pakistan is at 7th in number among the most serious atmosphere influenced nations. For this Government of Pakistan established, Global Change Impact Studies Centre (GCISC act 2013) to cover this region in volume building, information distribution, support to policymakers and national planners related to numerous divisions such as food, water, agriculture, forestry, health, biodiversity, environment, food, livestock, and advanced technologies in Pakistan. These renewable projects will be helpful at the household level. So, to fill the gap and analyze the key reasons of the continuing energy disaster, we try to measure the current development of renewable energy resources including, solar, wind, biogas, micro Hydel, and bagasse.

This research further analyzes policy issues linked to renewable energy technology resources and securities to resolve the current energy crisis in Pakistan. Among the rundown of a couple of countries; Pakistan is also vulnerable to the aftereffects of environmental change. For this, the ministry of climate change Pakistan focused on renewable energy sources and their policies are given as (see Table1).

The motivation and contribution of this study as follows: first, present study focuses on renewable energy, energy security, energy demand, energy supply, and energy import; second, we will estimate the sectorial energy consumption and situation of energy by source; third, study focuses on the solar energy and solar energy policies regarding Pakistan Energy Vision (2025) and Vision (2035). The analysis is based on two scenarios which enhance the renewable and non-renewable energy resources in Pakistan from 2014-2035. Finally, to analyze the energy security in Pakistan, we applied MARKAL (Market Allocation) method based on three scenarios i.e. base case and two reduction scenarios i.e. 5\%, 10\% during 2014-2035. For future energy security, the policy recommendations are provided based on outcomes because such measurements and policies do not exist. The present study like many other studies helps to improve our knowledge and understanding of energy security-related problems. Thus, according to the best of our knowledge, this study is the first of its nature related to analysis.

The research is organized as follows: Section 2 shows the literature review; section 3 identifies an overview of solar energy. Section 4 includes the energy security, section 5 provides policy recommendation and section 6 gives the conclusion.

Table 1: Climate change policies related to renewable energy Pakistan (NCCP, 2012).

\begin{tabular}{|l|l|}
\hline Serial no. & Threats \\
\hline 1 & Focus on the growth and elevation of hydropower production. \\
\hline 2 & $\begin{array}{l}\text { Encourage the development of clean energy resources such as wind, solar, bio-energy, and } \\
\text { geothermal energy. }\end{array}$ \\
\hline 3 & $\begin{array}{l}\text { The Government should take action in making innovative building designs with solar } \\
\text { energy. Firstly starts from the public sector buildings. }\end{array}$ \\
\hline 4 & $\begin{array}{l}\text { Discover the opportunities of getting technical knowledge which will help in getting clean } \\
\text { coal technologies for the huge coal reserves in the south of Pakistan. It should be applied } \\
\text { for on i.e. Pressurized-Fluidized-Bed Combustion (PFBC) and Near-Zero Emission } \\
\text { Technology (NZET) for these coal assets and their presence in future pulverized coal } \\
\text { Integrated Gasification Combined Cycle (IGCC) systems. }\end{array}$ \\
\hline 5 & $\begin{array}{l}\text { Power should create by utilizing municipal waste. } \\
\text { For the distribution losses, decrease in transmissions; ensure best quality management of } \\
\text { energy creation and energy supply. }\end{array}$ \\
\hline
\end{tabular}




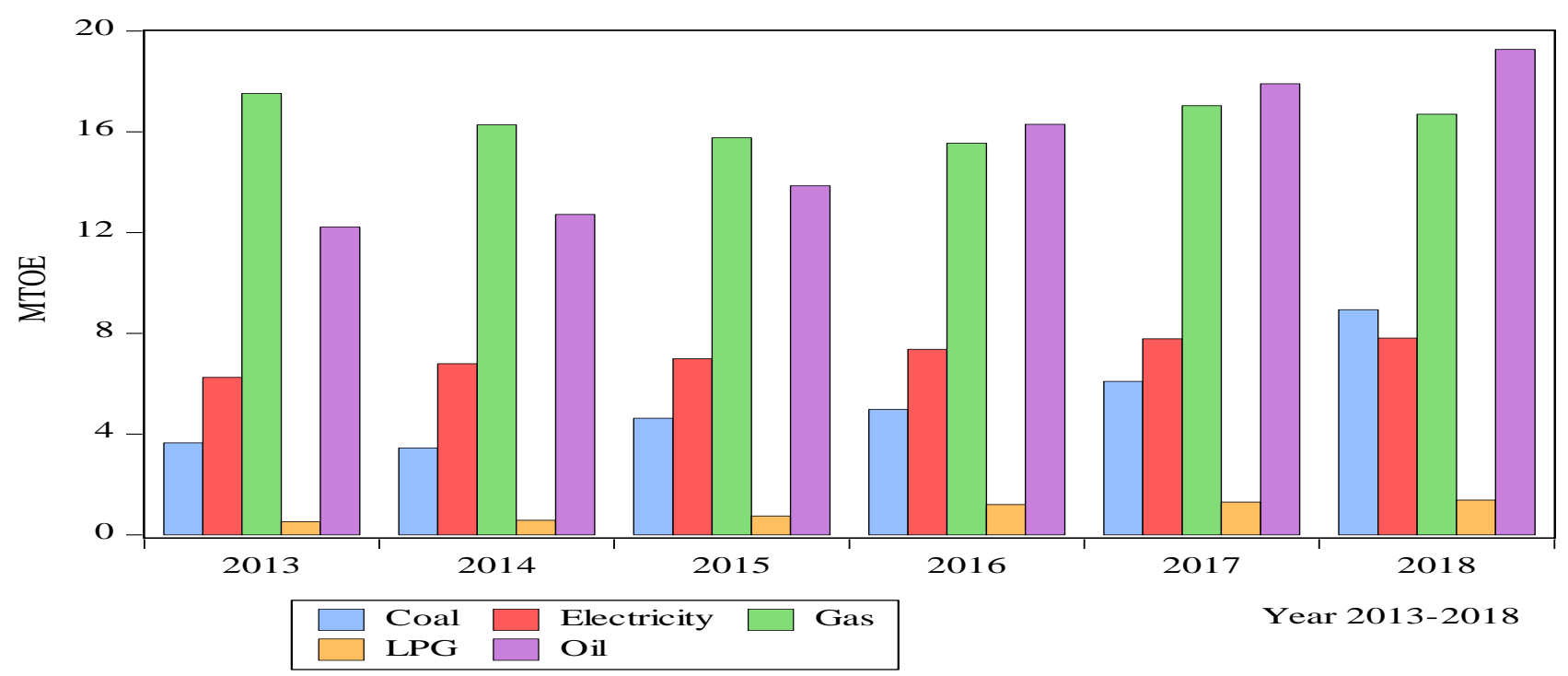

Fig.1. Final energy consumption in Pakistan during 2013-2018.

Source: (HDIP, 2018).

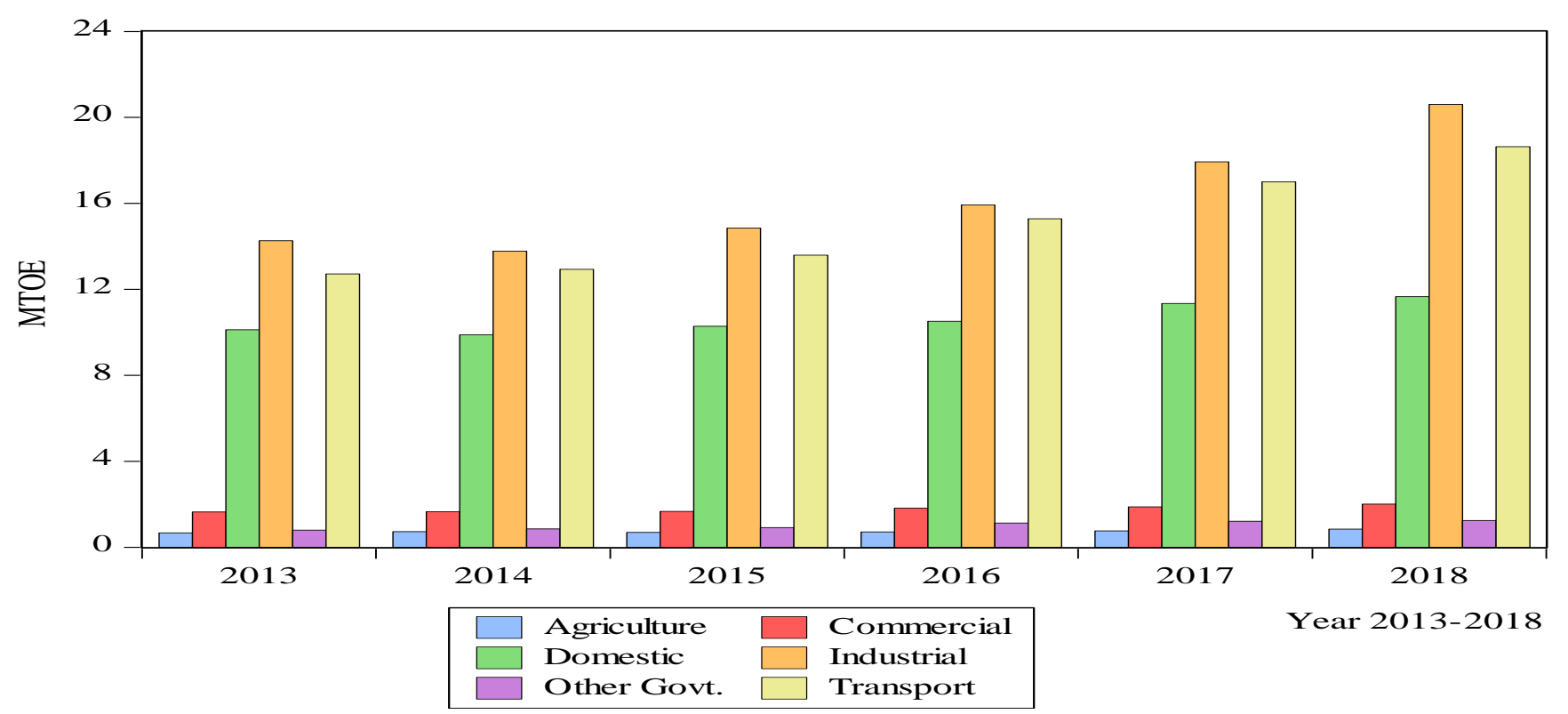

Fig.2. Final energy consumption by various sectors in Pakistan during 2013-2018.

Source: (HDIP, 2018). 
Coal

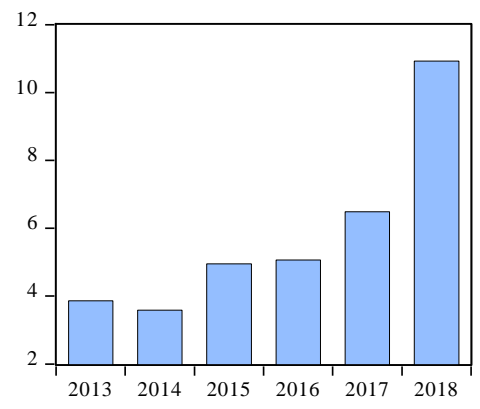

Imported Electricity

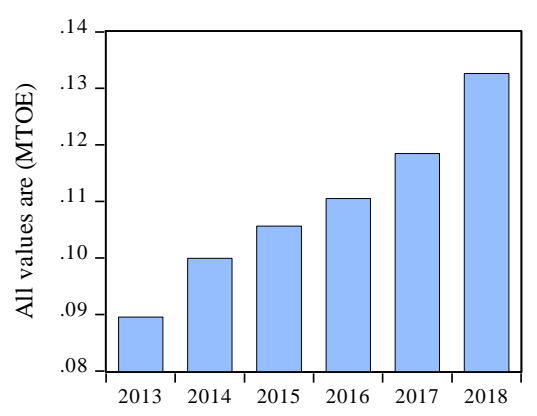

Nuclear Electricity

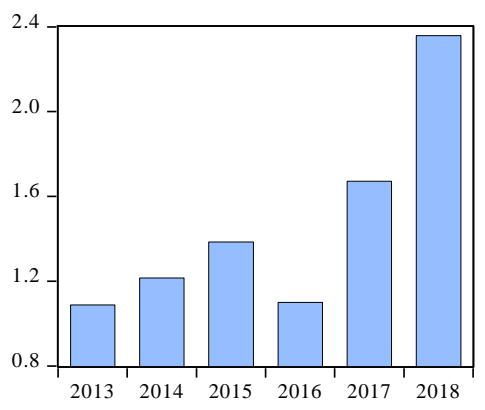

Gas

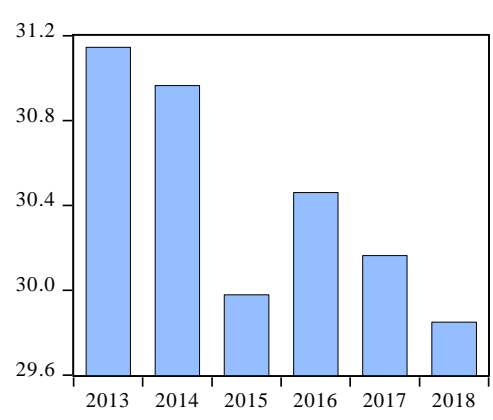

LNG Import

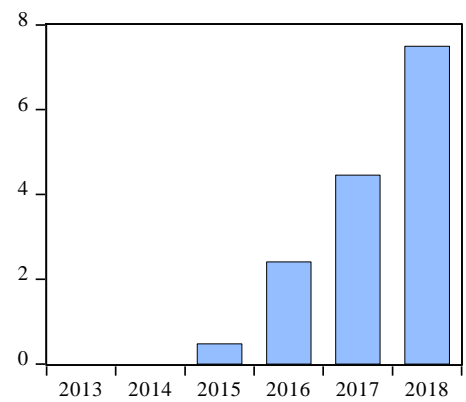

Oil

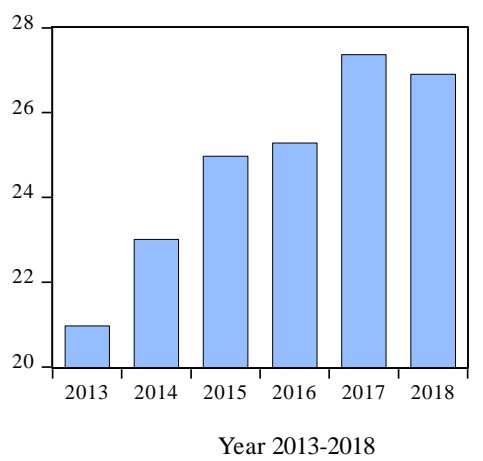

Hydro Electricity

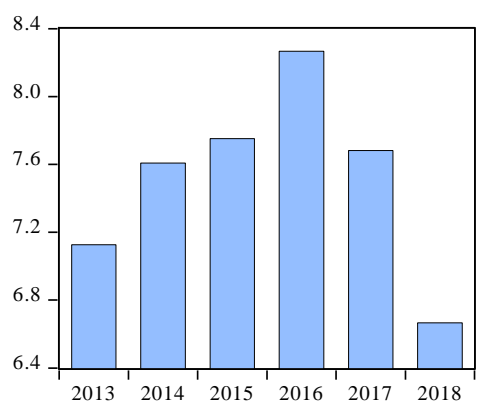

LPG

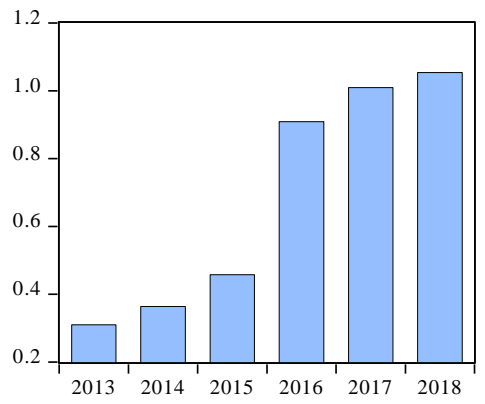

Renewable Electricity

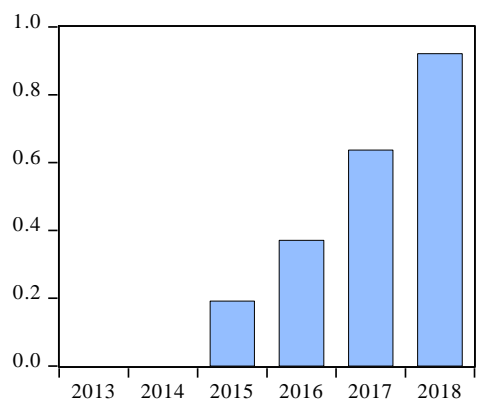

Fig.3. Primary energy supply by the source in Pakistan during 2013-2018. Source: (HDIP, 2018).

\section{Review of the Study}

Energy plays an important part in economic and social change (Raza et al., 2019). Pakistan has ample clean energy sources which are similar to Bangladesh, India, Iran, and many other countries in the region (Khare et al., 2013). Current situation of the country's future supply, demand and sectorial consumption are given in (Fig. 1-3). A study of (Aslam et al., 2015) for Pakistan, generally the vitality utilization in Pakistan has expanded like creating nations and is required to pursue a similar pattern. It is due to the gap among supply and demand which has been stretched and shortfall touched at a higher level. The shortage of electricity has also caused industries, for this agriculturalists and industrialists need for energy substitutes (Shakeel et al., 2016). According to (Pasha et al., 2013), renewable energy production is two and half times more costly than other power generation. It needs maintenance and repair costs which are not accessible but useful for environment and energy demand. According to (Commission, 2015), the GOP is facing the following deficiencies of energy due to the following factors; inefficient energy mix, import of oil, unable to get coal and oil reserve due to modern technology, lowest share of coal than neighboring countries i.e. India and China, decreasing share of hydropower, less share of solar energies, problems with local related engineering industries, and tariff structure. For this, GOP made short, medium and long-run plans for the energy improvement for the social and economic development. The electricity generation plan is based on oil, coal, gas, hydro, nuclear and clean energy sources. According to (Lin and Raza, 2019a), Pakistan has signed coal power (capability of $7560 \mathrm{MW}$ ) and clean energy (capability of $2790 \mathrm{MW}$ ) with China Pakistan Economic Corridor (CPEC). Initially, China has invested $\$ 6.4$ billion (b) for coal projects while $\$ 8.8 \mathrm{~b}$ for clean power production. 
Peters et al., 2017; Peters et al., 2017; and de Leon Barido et al., 2018, have identified that in achieving the global goals energy efficiency play an essential role related to energy security; Bouton et al., 2010; Bouton et al., 2010; and Peters et al., 2017 for economic efficiency and IEA, 2017 for climate change and local pollution reduction. According to Demski et al., 2015, energy security in the form of a reliable, safe, and is affordable for the public. For example, Turkey energy security framework ensures the energy sources, production and providing the highest level of energy efficiency (Bulut and Muratoglu, 2018). To develop economy and energy security, many countries import fuel, for example, (Song et al., 2019) analyzed China's energy security and found that the national energy security indexed declined from 1990 to 2014, energy supply index decreased in 1990 and increased in 2010, environmental and economic-technical sub-index increased from 1990-2000 while increased during 2010-2014; (Ang et al., 2015) measured the energy security of Singapore and estimated that energy security remained stable during 1990-2010. They also analyzed that ecological-index improved due to declining of economic-sub-index and two growing sun-indexes such as economic and environment; (Yao and Chang, 2014) analyzed energy security for China and found best during 1981 to 1985 and then declined between 1995 and 2005. To improve energy security risk, the government should improve the domestic energy framework, productivity, and renewable resources (Lin and Raza, 2019b). This will mitigate CO2 emissions, oil import, and imported cost of a country. Similarly, (Le and Nguyen, 2019) used a generalized least square model for 74 countries and estimated that energy security increases the economic growth of whole countries.

To avoid the risk, they developed a sustainable energy model with the help of the Government. More than 30 per cent population of Pakistan is living without electricity (Global Wind Energy Outlook, 2012). According to the (AEDB, 2014), currently, over 40,000 villages and 44 per cent of the rural households are away from the grid. For the betterment of these areas, renewable energy can be accessed. For this, (Chaudhry et al., 2009) identify that Baluchistan province of Pakistan has the best solar potential with the average sunlight of $8.5 \mathrm{~h}$ in a day and 20 $\mathrm{MJ} / \mathrm{m} 2$ of solar isolation. Additionally, Sindh and desert areas of Punjab provinces have high solar potential. Many researchers discussed the advantages of solar energy for example, (Jebli and Youssef, 2017) for Morocco's agriculture and social-economic development; (Asif, 2009)(Asif, 2009) for Pakistan's energy cost, security and sustainable energy; (Jianqi et al., 2014) measured for Iran's solar feasibility for rice irrigation; (Atam and Arteconi, 2017) for apricot orchards; (Ali, 2018) for solar water pumping in Sudan; (Kumar et al., 2015) for agriculture irrigation in India and (Xu et al., 2013) for China water irrigation.

The literature shows a secure, energy development and productive evidence from different countries. Currently, evidence from the South Asian countries, renewable energy technologies have become a tool for bounding GHG emanations and giving combined solutions in many countries (Geng et al., 2016)(Geng et al., 2016); (Morita and Matsumoto, 2018); (Quirapas et al., 2015); (Zhang et al., 2017)(Zhang et al., 2017). (Hu et al., 2017); (Kahouli, 2018); (Nasreen et al., 2017) identified that renewable energy is a friendly environment, affordable, and clean energy. It also effects on the economic development of a country. Pakistan is situated in South Asia and has many issues related to population, economy and energy security. For this, many researchers focused on it. For example, (Costanzo et al., 2018); (Jakica, 2018)(Jakica, 2018) found that population, economic growth, plentiful energy sources inspire in accepting renewable energy sources in South Asian countries. It is, therefore, many South Asian countries including Pakistan have started working in growing the share of clean electricity. The major objective is to decrease dependence on fossil fuels (Jakica, 2018)(Jakica, 2018). Moreover, the gap between possible supply and energy demand may effect on the social and economic growth (Lin and Raza, 2019a). According to (Ahmed et al., 2017)(Ahmed et al., 2017); (Lin and Raza, 2019a) identified that clean energy sources such as solar, wind, hydropower, biomass contains a lower carbon footprint. The continuous growth of clean energy technologies could lead urban areas away from the prime energy resources (Terziotti et al., 2012); (Wei et al., 2014); (IRENA, 2018); (Khuong et al., 2019)(Khuong et al., 2019). The literature says that some nations consider releasing indigenous policy for clean energy, but the Government involvement is still based on political blockage in the regions. For example, new clean energy policy in Malaysia was released in 2010 according to the governance rules which have created problems in 2017 due to approval and regulations of the energy sector (Yatim et al., 2016). Similarly, (Sustainable Development, 2017) identified a structure and process of sustainable governance growth in the review 2017 of the high-level political forum in the Philippines. The general governance policies were released in 2013 by Thailand. For this, the Alternative Energy Development Plan (AEDP) ensures that relevant agencies and public sectors undertake their responsibilities in a good manner but could not achieve all targets. According to (Tongsopit et al., 2015), the governance of Thailand is weak in the energy sector due to public involvement, independence, transparency, and accountability. For this, the Energy Regulatory Commission (ERC) of Thailand has been 
assessed in the favor of autonomy and independence from the political meddling. The next section includes the energy situation in Pakistan.

\section{Overview of Solar Energy in Pakistan}

\subsection{Electrification from Renewable Energy Sources (RES)}

The portion of RESs in the existing era is significant because of the acute crisis. Due to the shortage of indigenous hydrocarbon resources, excess use of fossil fuels, unstable prices of fuel, climate change leaves Pakistan with no other choice but to attend on the growth of existing and plentiful clean energy sources for the electricity production. According to (Shakeel et al., 2016) 'RES' is the emergent as one of the widest developing sources of energy production IN the globe. REN 21 clarifies that global capacity of clean electric energy from the various sources such as bio, geothermal, hydro, ocean, solar, and wind power was 2,017 gaga watts (REN21, 2017). Evidence from REN21 shows that Pakistan has reduced solar Feed-in-Tariff (FIT) was reduced by $36 \%$ for long-term contracts to solar products. 'RES' electrification is fasting momentum worldwide. The rising in political and investment support programs have allowed clean technologies to prosper and making accessible energy for the friendly environment, especially in the off-grid areas. As discussed in Fig.3, renewable energy is increasing each year which shows that Pakistan is the best in renewable energy generation. The demand for electricity is growing, while projections from the supply side are not positive. For this, Pakistan should take radical steps to safeguard the energy demand balances. In order to achieve energy demand goals, the country must focus on its rich and natural available renewable energy sources such as solar, wind, biogas etc. In this way, RES surely provides potential to supplement future requirements sustainably. This section briefly discusses the clean energy sources and their potential in Pakistan.

\subsection{Renewable Energy in Pakistan}

Use of clean energy in Pakistan is inconsistent. Currently, Pakistan has 32 solar power stations in various places of Punjab, Sindh, and KPK provinces; 46 wind power station working in Punjab and Sindh provinces; 4 biomass stations working in Punjab, Sindh, and KPK provinces; 43 bagasse power stations are working in Punjab and Sindh provinces (SDPI, 2014). Renewable energy production detail is given in Table 2. The domestic use of clean energy is still at a low level as compared to other countries of the word. Table 2 provides total renewable energy capacity and generation from 2016-2018. Overall, solar and wind energy generation is higher than the biomass and bagasse and hydel power. This section measures the individual recent potential of clean power and needs policy recommendations. Pakistan has many strategies and national plans concerning the promotion and growth of clean energy inside the country. In table 1, climate change policies are provided. Various agencies in Pakistan for example, Intended Nationally Determined Contributions (INDCs); Pakistan energy vision-2035; National Climate Change Policy (NCCP); Vision 2025, and Climate Public Expenditure and Institutional Review (CPEIR) of Pakistan have made many endeavors to achieve maximum use of clean energy and energy output. The government of Pakistan has a history of development, research \& development (R\&D) when it comes to clean energy. Though, in spite of its development in the academic and private sectors, Pakistan has not attained its renewable energy targets. For example, according to (SDPI, 2014)(SDPI, 2014), the national solar energy target until 2020, 2025, 2030, and 2035 values are 30, 170, 800, and $900 \mathrm{MW}$. For this, Government has made budget scenarios for the future solar energy targets which are increasing 7684.79 million rupees for 2020, 204413.32 million rupees for 2025, 207051.23 million rupees, and 230244.95 million rupees for 2030. Similarly, other renewable sources have similar increasing power and budget for future energy targets. This will help in the energy crisis, energy potential and energy security. Such policies, future targets, and high-volume production of energy will decrease the cost of consumer bills and decrease the dependency on foreign energy suppliers. Moreover, renewable energy is fruitful for the clean climate because INDC found carbon emission roots within the Pakistan (Commission, 2015); (NCCP, 2012). For this Pakistan has already signed COP-21 in Paris for the betterment of climate change.

Table 2: Provincial electricity generation by renewable energy projects

\begin{tabular}{|l|l|l|l|l|}
\hline Year & Technology & Province & Capacity & Generation \\
\hline 2016-2017 & $\begin{array}{l}\text { Solar Energy } \\
\text { (Photovoltaic) }\end{array}$ & All over Pakistan & $0.2 \mathrm{MW}$ & $438 \mathrm{MWh} /$ Year \\
\hline & $\begin{array}{l}\text { Biomass } \\
\text { (Biogas) }\end{array}$ & All over Pakistan & $0.011 \mathrm{MW}$ & $\begin{array}{l}\text { 43.8MWh/Year (in terms of } \\
\text { electricity generation) }\end{array}$ \\
\hline & Micro Hydel & KPK \& Gilgit / & $9.7 \mathrm{MW}$ & $42,486 \mathrm{MWh} /$ Year \\
\hline
\end{tabular}




\begin{tabular}{|l|l|l|l|l|}
\hline & & Baltistan & & \\
\hline & Wind Energy & Sindh, Baluchistan & $150 \mathrm{MW}$ & $540 \mathrm{MWh} /$ Year \\
\hline $2017-2018$ & & & & \\
\hline & Solar & All over Pakistan & $430 \mathrm{MW}$ & $768000 \mathrm{MWh} /$ Year \\
\hline & Wind & Sindh, Baluchistan & $1006 \mathrm{MW}$ & $2101000 \mathrm{MWh} /$ Year \\
\hline & Bagasse & Punjab, Sindh \& KPK & $201 \mathrm{MW}$ & $988000 \mathrm{MWh} /$ Year \\
\hline
\end{tabular}

Source: Pakistan Energy Yearbook, 2017-2018

\subsection{Solar Energy Cost Parity}

Pakistan is blessed with huge potential of solar and wind resources that can be utilized for energy creation. GOP has decided to grow new renewable energy projects especially wind and solar based on budget availability. According to (SDPI, 2014), GOP has included various renewable and non-renewable energy projects in two scenarios (see Table 3, 4). Over the last five years, eighteen wind power projects of 1006MW accumulative capacity are supplying electricity to the national grid, while five solar energy projects of 430MW capacity have been made operational in 2018. Power generation from bagasse, approximate six sugar mills with a capacity of 201MW are working. The comparison of different renewable energy sources and non-renewable energy sources are given below Table 3, 4. According to the latest two scenarios provide heavy investment on solar, wind, and bagasse from 2014 to 2035. According to (IRENA, 2015), the average value of PV modules drops by nearly 80\%. At the same time, the price of wind turbines also fell by 33\%. This situation can make Pakistan most prosperous in energy growth. Technology is the main barrier in Pakistan because of the high cost in technology import. Additionally, Pakistan seems low-cost coal and gas energy for the future which is not supportive of climate and human life. For this, policymakers must take actions towards technologies making renewables more instantly cost-effective. Moreover, in Pakistan, most of the electric companies have a monopoly on electric distribution, and they should encourage cost-effectiveness and energy efficiency measures. For example, the World Bank's Regulatory Indicators for Sustainable Energy (RISE) advise a task force to screen and evaluate energy output in a country (World Bank, 2016)(World Bank, 2016). So far, the Government of Pakistan has approved the maximum budget for the renewables in promoting the energy efficiency of Pakistan.

Table 3: Investment scenarios of renewable energy and non-renewable projects from 2014-2035

\begin{tabular}{|l|l|l|l|l|l|l|l|}
\hline & $\begin{array}{l}\text { Non-renewable } \\
\text { energy }\end{array}$ & & & & & \\
\hline & & Scenario A & & & & & \\
\hline Year & Low Btu & $\begin{array}{l}\text { Imported } \\
\text { Coal }\end{array}$ & $\begin{array}{l}\text { Local } \\
\text { Coal }\end{array}$ & $\begin{array}{l}\text { Waste } \\
\text { Power }\end{array}$ & Shale & & \\
\hline 2014 & 49.2 & 68.33 & 74.3 & 0 & 0 & & \\
\hline 2015 & 19.51 & 0 & 0 & 0 & 0 & & \\
\hline 2016 & 29.2 & 186.2 & 195.8 & 0 & 0 & & \\
\hline 2020 & 13.94 & 198.1 & 365.44 & 36.83 & 0 & & \\
\hline 2025 & 0 & 12.1 & 12 & 39.8 & 0 & & \\
\hline 2030 & 9.95 & 20.1 & 20 & 76.7 & 0 & & \\
\hline 2035 & 9.95 & 10.6 & 10.5 & 39.8 & 0 & & \\
\hline & Renewable energy & Scenario A & & & & & \\
\hline & Geothermal & Bagasse & Wind & Biomass & Solar & Thermal & Hydro \\
\hline 2014 & 0 & 0 & 14.3 & 0 & 0 & 150.02 & 74.5 \\
\hline 2015 & 0 & 23.9 & 1.82 & 0 & 0 & 171.01 & 223.2 \\
\hline 2016 & 0 & 28.4 & 2.09 & 1.97 & 26.63 & 0 & 568.53 \\
\hline 2020 & 7.43 & 17.42 & 2.62 & 1.97 & 7.68 & 0 & 1320.1 \\
\hline 2025 & 7.43 & 47.3 & 5.2 & 11.9 & 204.4 & 0 & 2911.4 \\
\hline 2030 & 59.42 & 47.3 & 7.6 & 39.42 & 207.1 & 0 & 1937.9 \\
\hline 2035 & 62 & 10 & 5.04 & 24.81 & 230.3 & 0 & 2482.9 \\
\hline
\end{tabular}

Values are given in Pakistan Billion rupees (Rs.)

Source: Pakistan Energy Yearbook, 2017-2018 (HDIP, 2018) 
Table 4: Investment scenarios of renewable energy and non-renewable projects from 2014-2035

\begin{tabular}{|c|c|c|c|c|c|c|c|}
\hline & $\begin{array}{l}\text { Non-renewable } \\
\text { energy }\end{array}$ & & & & & & \\
\hline & & Scenario B & & & & & \\
\hline Year & Low Btu & $\begin{array}{l}\text { Imported } \\
\text { Coal }\end{array}$ & $\begin{array}{l}\text { Local } \\
\text { Coal }\end{array}$ & $\begin{array}{l}\text { Waste } \\
\text { Power }\end{array}$ & Shale & & \\
\hline 2014 & 49.2 & 68.33 & 74.3 & 0 & 0 & & \\
\hline 2015 & 19.51 & 0 & 0 & 0 & 0 & & \\
\hline 2016 & 29.2 & 186.2 & 195.8 & 0 & 0 & & \\
\hline 2020 & 13.94 & 198.1 & 365.44 & 36.83 & 0 & & \\
\hline 2025 & 0 & 12.1 & 12 & 39.8 & 0 & & \\
\hline 2030 & 9.95 & 20.1 & 20 & 76.7 & 0 & & \\
\hline \multirow[t]{3}{*}{2035} & 9.95 & 10.6 & 10.5 & 39.8 & 0 & & \\
\hline & Renewable energy & Scenario B & & & & & \\
\hline & Geothermal & Bagasse & Wind & Biomass & Solar & Thermal & Hydro \\
\hline 2014 & 0 & 0 & 14.32 & 0 & 0 & 150.02 & 74.5 \\
\hline 2015 & 0 & 23.9 & 1.82 & 0 & 0 & 171.01 & 223.2 \\
\hline 2016 & 0 & 28.4 & 208.64 & 1.97 & 53.2 & 0 & 568.53 \\
\hline 2020 & 7.43 & 17.42 & 260.81 & 1.97 & 175.6 & 0 & 1320.1 \\
\hline 2025 & 7.43 & 47.3 & 1542.3 & 11.89 & 363.73 & 0 & 2911.4 \\
\hline 2030 & 59.42 & 47.3 & 996.63 & 39.42 & 1243.3 & 0 & 1937.9 \\
\hline 2035 & 62 & 10 & 2036.7 & 24.81 & 373.3 & 0 & 2482.9 \\
\hline
\end{tabular}

Values are given in Pakistan Billion rupees (Rs.)

Source: Pakistan Energy Yearbook, 2017-2018(HDIP, 2018)

\subsection{Energy Security Indicators for Energy Demand, Energy Supply and Energy Import}

As discussed in the literature, energy security plays a key role in the development of a country. For this, we have utilized the MARKAL (market-allocation) method which has been estimated by (Shakya and Shrestha, 2011); (Shrestha and Shakya, 2012); (Martchamadol and Kumar, 2012). For this, different indicators are used to measure energy security i.e. NEIR, VI, and NOID illustrated in Table 5. These outcomes are based on energy consumption data and measured in the form of reduction scenarios of the base case, 5\%, and 10\% during 2015-2035 (see Table 6). Thus, these variables will support policy makers to analyze the demand, supply and import related information. Table 6 shows estimations of NOID, VI, and NEIR. NOID shows maximum dependence on oil and found a decreasing trend in 2035 in the base case scenario. The main reason is the minimum use of oil in transport and agriculture sector of Pakistan (Ministry of Finance, 2018). This will decrease oil import, increase energy security and negatively impact on NEIR. NOID and VI are showing a decreasing trend which is evidence of increasing renewable energy resources. Furthermore, the reduction scenarios at $5 \%$ and $10 \%$ would be significant if the alternative energy resources should be applied and oil import is reduced.

Table 5: Details Of Energy Security Indicators

\begin{tabular}{|lc|c|l|}
\hline $\begin{array}{l}\text { Net Energy Import } \\
\text { Ratio (NEIR) }\end{array}$ & NEIR $=\frac{\text { NEI }}{\text { DS + NEI }}$ & $\begin{array}{l}\text { NEI is the net energy import (Mtoe). } \\
\text { DS is the domestic sector supply (Mtoe). }\end{array}$ \\
\hline $\begin{array}{l}\text { Vulnerability Index } \\
(\mathrm{VI})\end{array}$ & $\mathrm{VI}=\frac{\mathrm{EEI}}{\mathrm{GDP}}$ & $\begin{array}{l}\text { EEI is the expenditure on energy import (Million } \\
\text { US\$). } \\
\text { GDP is the gross domestic product }\end{array}$ \\
\hline $\begin{array}{l}\text { Net Oil Import } \\
\text { Dependency (NOID) }\end{array}$ & NOID $=\frac{\text { NOI }}{\text { OPED }}$ & $\begin{array}{l}\text { NOI is the net oil import (Mtoe ). } \\
\text { OPED is the oil primary energy demand (Mtoe). }\end{array}$ \\
\hline
\end{tabular}


Table 6: Energy security and import reduction targets based on 5\%, 10\% reduction scenarios.

\begin{tabular}{|l|l|l|l|}
\hline Year & NEIR & VI & NOID \\
\hline & Base case scenario & & \\
\hline $2015-2020$ & 37.97 & 0.016 & 0.725 \\
\hline $2020-2025$ & 56.66 & 0.0030 & 0.509 \\
\hline $2025-2030$ & 75.64 & -0.0097 & 0.296 \\
\hline $2030-2035$ & 94.20 & -0.0233 & 0.096 \\
\hline & $5 \%$ & & \\
\hline $2015-2020$ & 36.07 & 0.015 & 0.689 \\
\hline $2020-2025$ & 53.82 & 0.003 & 0.84 \\
\hline $2025-2030$ & 71.85 & -0.009 & 0.28 \\
\hline $2030-2035$ & 89.49 & -0.022 & 0.092 \\
\hline & $10 \%$ & & \\
\hline $2015-2020$ & 34.17 & 0.014 & 0.65 \\
\hline $2020-2025$ & 50.99 & 0.002 & 0.45 \\
\hline $2025-2030$ & 68.07 & -0.008 & 0.266 \\
\hline $2030-2035$ & 84.78 & -0.021 & 0.087 \\
\hline
\end{tabular}

Source: Pakistan energy yearbook 2018. (HDIP, 2018)

\subsection{Socio-Cultural and Infrastructure Dynamics}

Socio-cultural dynamics play a vital role in the growth of clean energy and reducing carbon emissions. It is due to the actions of numerous social groups' i.e. native people, Government authorities, city authorities, media, suggested bodies, and political parties are directed by beliefs, taking interests, unbalanced resources, conflicting values, and complexity among the social relationships. Similarly, (Sovacool, 2017)(Sovacool, 2017); (Dahal et al., 2018) identified these ecological dynamics. (Dahal and Niemelä, 2016) showed that different departments, environmental establishments in that area, academic such as universities and research centers, energy companies, housing schemes and residents participate to the understanding carbon emissions and use of renewable energy resources. According to (Nawaz and Alvi, 2018) (Nawaz and Alvi, 2018)for Pakistan, energy safety is not only important for long-run benefits but also important for social-cultural, economic and environmental sustainability. Social awareness, renewable energy resilience, and political viability are critical for encouraging clean energy in Pakistan. For this, (Jung et al., 2016) identified that social awareness towards renewable energy can change city policies. For example, some residents are still not accepting the wind, biomass technologies. It is due to the high price which is not feasible to invest in clean sources and distribution of cities demographics. According to the (Ministry of Finance, 2018), 63.623\% population of Pakistan is living in rural areas which are decreasing due to facilities in urban areas. Furthermore, the population situation from rural-urban areas can create pollution. It is, therefore, current clean energy policies should be adapted to address the population growth in Pakistan.

The physical infrastructure, such as power plant, storage of energy, grids, heating networks, and charging points are the basic services for the formation of clean energy technologies. In Pakistan, yet there is no electric vehicle system. So, renewable energy and bio-energy can be utilized in the heating systems at lower-level. Besides, huge coal reserves in Pakistan can be utilized in energy production by applying clean technologies. The research and development, and innovative electric policies can resolve the energy crisis and energy security in Pakistan. Additionally, due to the limited energy storage, the use of power storage batteries should be utilized at small and large-level because the renewable energy resources fluctuate in energy generation. In these cases, the financial encouragements are necessary for the early stage of development. For this, energy ministry and ministry of climate change of Pakistan should formulate effective policies for the growth of these infrastructures.

\subsection{Economic Dynamics}

Based on renewable energy technologies, the ministries should formulate strong policies and related business models. These business models with clean technologies i.e. solar, biomass, and wind should apply to the local energy markets. Currently, the prices are high at small-scale but the financial encouragement can raise the interest of consumers. Overall, the global investment in renewable energy in 2017 was \$333.5billion which has increased by $\$ 251.6$ billion more than $10 \%$ of the last year (Bloomberg, 2017). In 2018, Pakistan has generated renewable 
energy from 2,668GWh to 3,857GWh with a growth of $44.6 \%$ than the previous year (HDIP, 2018). Table 3 and Table 4 measure the best scenarios and cost-effective for renewable energy sources.

\subsection{Energy Security As The Policy Discussion}

Different challenges related to clean energy technologies showed a comparison between fossil fuel energy and renewable technologies. The disparity in the energy supply mix and electricity production sources have created significant problems related to energy security and ecological sustainability(Lin and Ahmad, 2016). According to (Owusu and Asumadu-Sarkodie, 2016), renewable energy decreases energy imports, contribute to energy supply, cost, and provide opportunities to improve energy security. The natural resources are the most economical resources in the world. Thus, the existing research focuses on the relationship between energy crisis, and energy security coming from natural resources. According to a survey, the country's natural resources grow economic growth. Energy security provides confidence by using native resources, spreading the energy to the rural areas and caring for the atmosphere by decreasing CO2 (carbon dioxide) emissions. According to the 2011 framework of Government's new policy, focused on the domestic resources and confirmed that at least 5\% of energy supplies through renewable by 2025 (AEDB, 2011). Similarly, (IRENA, 2018) measured that clean energy not only provides benefit to weather change and pollution reduction but also boost employment, financial development, and energy security. In short, Government of Pakistan (GOP) should revisit the national and international energy security plan and should attention on local issues with domestic, alternative and clean resources to challenge the current energy crisis and to provide the upcoming power demand of Pakistan.

\section{Policy Recommendation for Pakistan}

Our findings propose experts should make projects for the generation of clean energy and energy security in Pakistan as follows:

First, there is easy access to solar, wind, biomass, and hydel energy sources in the provinces Punjab, Sindh and few areas of Khyber Pakhtunkhwa (KPK) are suitable for solar and wind energy while northern areas of Pakistan can produce clean energy by water which has been discussed in (SDPI, 2014)(SDPI, 2014); (Commission, 2015)(Commission, 2015). Second, tax policy should be revised to attract local and foreign investors to exploit the clean energy resources in the country. This will improve the energy security, human life, fresh climate, jobs, and economic growth of a country. Third, according to the (Ministry of Finance, 2018), 63.623\% population of Pakistan is living in rural areas of five provinces Balochistan, Sindh, Punjab, Khyber-Pakhtunkhwa (KPK), and Gilgit Baltistan. The Maximum population of Pakistan is connected with agriculture, for this, it is suggested that the Government should help farmers to install small scale solar and industrial projects to increase the level of their income. Fourth, according to solar energy research center (SERC), 50, 000 villages are far away from the national grid, so providing each house a solar panel would be cost-efficient and would authorize people both socially and economically. In many villages, people are still using dung, deforestation, and wood fire for cooking. For this, the Government should give subsidy to villagers on the solar panel, biomass energy, and support private companies. Fifth, according to the (PPIB, 2002)(PPIB, 2002), it was not focused on clean energy and human resources but also focused on the target production of $1500 \mathrm{MW}$ of renewable energy by 2020 . Sixth, for the betterment of energy security, energy import dependency should decrease based on energy substitution. This would increase friendlyenvironment and improve the living standard of people (Lin and Raza, 2019b). These policies will lessen the price of power production, raise income, agriculture production, trade openness, and clean climate. Climate change policies are mentioned in Table 1.

\section{Barriers to Renewable Energy}

Many barriers have banned the fast integration of clean energy in Pakistan during the last two decades (Farooqui, 2014)(Farooqui, 2014). These are regulatory barriers, policy barriers, economic, financial, fiscal barriers, institutional barriers, energy market barriers, information, social barriers, and technological barriers (Mirza et al., 2009). Alternative energy development board (AEDB) has also discussed some barriers during the last few years related to policy and regulatory authorities for wind, solar, and biomass. The current distribution of renewable energy is given in table 2. Additionally, the current circular debt of Pakistan is also a major problem for the power sector and has become an important barrier for energy growth in Pakistan. According to the power minister, the circular debt has boosted to 1.3 trillion rupees due to poor governance practices, power transmission, massive line losses, and grid stations efficiency (Pakistan Today, 2018). Crucial improvements are needed to produce electric generation capacity, improve transformation system and distribution network. 


\section{Conclusion}

This study analyzes Pakistan's energy crisis, energy security, energy demand, energy supply, and renewable energy. We focused on renewable (solar energy) and non-renewable energy for the understanding gap between demand and supply. The significance of energy supply and demand is not only for economic development but also for the present and upcoming generations. Overall, our study discusses that solar power is fruitful than wind energy. Most of the Pakistani belt is sunny which is more feasible and energy-efficient after fossil fuels, while wind turbines can only be adjusted in deserted or coastal areas of Pakistan. For this, we applied renewable and nonrenewable energy scenarios and energy security scenarios by using the MARKAL approach from 2014-2035. Our analysis shows that total indigenous production of energy is $46.725 \mathrm{Mtoe}$ while renewable energy production is $3857 \mathrm{GWh}$ during $2017-2018$. Solar energy production is $768 \mathrm{GWh}$ which is increasing every year which is sufficient to facilitate the domestic consumers. According to energy security reduction scenarios, Pakistan would improve renewable and energy security until 2035 with significant possibilities. In the end, the scenarios budget identifies that renewable energy sources are much imperative for the betterment of Pakistan's development. Renewable energy sources have provided environmental sustainability and economic growth of the off-grid areas of Pakistan.

\section{Limitations}

This study has also some limitation. The political situation puts robust stress on the influence of renewable energy sources to energy security through indigenous power generation i.e. CPEC, Vision-2025, and Pakistan Energy Vision-2035 are the best renewable energy policymakers. The policies should focus on collaboration between federal, provincial, and security agencies in the limitation framework. The project detail, capability and feasibility should be included. Current projects such as CPEC, Pakistan energy vision-2035, and current policies can improve the ability of Pakistan to reach its potential. Limitation of data is also a challenge because of improper websites. Another reason is that Pakistan has stepped down in clean energy only a few years ago. It is, therefore, technical staff related to these projects is limited which may reduce the energy potential. Furthermore, future researchers can conduct across various industries and housing societies in different cultures for making it successful.

\begin{tabular}{|c|c|c|c|}
\hline Abbreviations & & & \\
\hline $\mathrm{CO} 2$ & Carbon dioxide & CPEC & China Pakistan Economic Corridor \\
\hline MW & Megawatt & IEA & International Energy Agency \\
\hline LPG & Liquefied Petroleum Gas & $\mathrm{MJ} / \mathrm{m} 2$ & Mega Joule Square meter \\
\hline $\begin{array}{l}\text { MTOE } \\
\text { LNG }\end{array}$ & $\begin{array}{l}\text { Million Tons of Oil Equivalent } \\
\text { Liquefied Natural Gas }\end{array}$ & $\begin{array}{l}\text { GHG } \\
\text { IRENA }\end{array}$ & $\begin{array}{l}\text { Greenhouse Gas } \\
\text { International Renewable Energy } \\
\text { Agency }\end{array}$ \\
\hline GCISC & $\begin{array}{l}\text { Global Change Impact Studies } \\
\text { Centre }\end{array}$ & AEDP & Alternative Energy Development Plan \\
\hline NCCP & National Climate Change Policy & ERC & Energy Regulatory Commission \\
\hline PFBC & $\begin{array}{l}\text { Pressurized-Fluidized-Bed } \\
\text { Combustion }\end{array}$ & & bi-directional causalities \\
\hline NZET & Near-Zero Emission Technology & KPK & Khyber Pakhtunkhwa \\
\hline $\begin{array}{l}\text { IGCC } \\
\text { INDC } \\
\text { AEDB }\end{array}$ & $\begin{array}{l}\text { Integrated Gasification Combined } \\
\text { Cycle } \\
\text { Intended Nationally Determined } \\
\text { Contributions } \\
\begin{array}{l}\text { Alternative Energy Development } \\
\text { Board }\end{array}\end{array}$ & $\begin{array}{l}\text { CPEIR } \\
\text { COP } \\
\text { RES }\end{array}$ & $\begin{array}{l}\text { Climate Public Expenditure and } \\
\text { Institutional Review } \\
\text { Conference of Parties } \\
\text { Renewable Energy Sources }\end{array}$ \\
\hline
\end{tabular}

\section{References}

AEDB (2011) Alternative and Renewable Energy Policy. Government of Pakistan. Alternative Energy Development Board. Available at: http://climateinfo.pk/frontend/web/attachments/data type/MoWP_AEDB\%20(2011)\%20Alternative\%20and\%20Renewable\%20Energy\%20Po.

AEDB (2014) Rural Electrification Program. Alternative energy development board. Available at: http://www.aedb.org/rep.htm.

Ahmed S, Islam MT, Karim MA, et al. (2014) Exploitation of renewable energy for sustainable development and overcoming power crisis in Bangladesh. Renewable Energy 72: 223-235. 
Ahmed T, Mekhilef S, Shah R, et al. (2017) ASEAN power grid: A secure transmission infrastructure for clean and sustainable energy for South-East Asia. Renewable and Sustainable Energy Reviews 67: 1420-1435.

Ali B (2018) Comparative assessment of the feasibility for solar irrigation pumps in Sudan. Renewable and Sustainable Energy Reviews 81: 413-420.

Aliyu AS, Dada JO and Adam IK (2015) Current status and future prospects of renewable energy in Nigeria. Renewable and sustainable energy reviews 48: 336-346.

Ang BW, Choong WL and Ng TS (2015) A framework for evaluating Singapore's energy security. Applied energy 148: 314-325.

Asif M (2009) Sustainable energy options for Pakistan. Renewable and Sustainable Energy Reviews 13(4): 903909.

Askari MB and Salarizadeh P (2019a) Superior catalytic performance of NiCo2O4 nanorods loaded rGO towards methanol electro-oxidation and hydrogen evolution reaction. Journal of Molecular Liquids 291: 111306.

Askari MB and Salarizadeh P (2019b) Ultra-small ReS2 nanoparticles hybridized with rGO as cathode and anode catalysts towards hydrogen evolution reaction and methanol electro-oxidation for DMFC in acidic and alkaline media. Synthetic Metals 256: 116131.

Askari MB, Salarizadeh P, Rozati SM, et al. (2019) Two-dimensional transition metal chalcogenide composite/reduced graphene oxide hybrid materials for hydrogen evolution application. Polyhedron 162: 201-206.

Aslam W, Soban M, Akhtar F, et al. (2015) Smart meters for industrial energy conservation and efficiency optimization in Pakistan: Scope, technology and applications. Renewable and Sustainable Energy Reviews 44: 933-943.

Atam E and Arteconi A (2017) Green energy-assisted frost prevention: a conceptual framework. Energy Procedia 141: $155-159$.

Bloomberg (2017) Clean Energy Investment Trends. Available at: https://data.bloomberglp.com/bnef/sites/14/2018/01/BNEF-Clean-EnergyInvestment-Investment-Trends2017.pdf.

Bouton S, Creyts J, Kiely T, et al. (2010) Energy efficiency: A compelling global resource. McKinsey Sustainability \& Resource Productivity.

Bulut U and Muratoglu G (2018) Renewable energy in Turkey: Great potential, low but increasing utilization, and an empirical analysis on renewable energy-growth nexus. Energy policy 123: 240-250.

Chaudhry MA, Raza R and Hayat SA (2009) Renewable energy technologies in Pakistan: prospects and challenges. Renewable and Sustainable Energy Reviews, 13((6-7)): 1657-1662.

Commission (2015) Pakistan 2025-One Nation-One Vision. Available at: https://www.pc.gov.pk/uploads/vision2025/Vision-2025-Executive-Summary.pdf.

Costanzo V, Yao R, Essah E, et al. (2018) A method of strategic evaluation of energy performance of Building Integrated Photovoltaic in the urban context. Journal of cleaner production 184: 82-91.

Dahal K and Niemelä J (2016) Initiatives towards carbon neutrality in the Helsinki Metropolitan Area. Climate 4(3): 36.

Dahal K, Juhola S and Niemelä J (2018) The role of renewable energy policies for carbon neutrality in Helsinki Metropolitan area. Sustainable cities and society 40: 222-232.

de Leon Barido DP, Suffian S, Kammen DM, et al. (2018) Opportunities for behavioral energy efficiency and flexible demand in data-limited low-carbon resource constrained environments. Applied energy 228: 512523.

Demski C, K.A. Butler C Parkhill, Spence A, et al. (2015) Public values for energy system change. Global Environmental Change, 34: 59-69.

Farooq MK and Kumar S (2013) An assessment of renewable energy potential for electricity generation in Pakistan. Renewable and Sustainable Energy Reviews 20: 240-254.

Farooqui SZ (2014) Prospects of renewables penetration in the energy mix of Pakistan. Renewable and Sustainable 
Energy Reviews 29: 693-700.

Firoz A and Intikhab U (2004) Empirical models for the correlation of monthly average daily global solar radiation with hours of sunshine on a horizontal surface at Karachi, Pakistan. Turk. J. Phys 28: 301-307.

Geng B, Zhang X, Liang Y, et al. (2016) Do favorable land price policy affect renewable energy industry? Evidence from photovoltaics. Journal of cleaner production 119: 187-195.

German Watch (2017) Global Climate Risk Index. Available at: https://germanwatch.org/sites/germanwatch.org/files/publication/16411.pdf.

Global Wind Energy Outlook (2012). Available at: https://hub.globalccsinstitute.com/publications/global-windenergy-outlook-2012.

Gurung A, Karki R, Cho JS, et al. (2013) Roles of renewable energy technologies in improving the rural energy situation in Nepal: Gaps and opportunities. Energy Policy 62: 1104-1109.

HDIP (2018) Pakistan Energy Yearbook. Ministry of energy (Petroleum Division) Hydrocarbon development institute of Pakistan. Available at: https://hdip.com.pk/contents.php?cid=32.

Hu L, Shi X, Qiao S, et al. (2017) Sources and mass inventory of sedimentary polycyclic aromatic hydrocarbons in the Gulf of Thailand: Implications for pathways and energy structure in SE Asia. Science of the Total Environment 575: 982-995.

IEA (2017) Sustainable Energy for All 2017-Progress toward Sustainable Energy. International Energy Agency (IEA) and the World Bank. Available at: https://www.worldbank.org/en/topic/energy/brief/sustainableenergy-for-all.

IRENA (2015) International Renewable Energy Agency. Available at: https://irena.org/ /media/Files/IRENA/Agency/Publication/2015/IRENA__REthinking_Energy_2nd_report_2015.pdf.

IRENA (2018) Renewable Energy Market Analysis: Southeast Asia.

Jakica N (2018) State-of-the-art review of solar design tools and methods for assessing daylighting and solar potential for building-integrated photovoltaics. Renewable and Sustainable Energy Reviews 81: 1296-1328.

Jebli MB and Youssef SB (2017) Renewable energy, arable land, agriculture, CO 2 emissions, and economic growth in Morocco. MPRA Paper No. 76798.

Jianqi H, Xianshuang C and Saiqing L (2014) Study on the distribution of cassava planting climatic regionalization in Guangxi based on ArcGIS. South China Agriculture 8(24): 131-132.

Jung N, Moula ME, Fang T, et al. (2016) Social acceptance of renewable energy technologies for buildings in the Helsinki Metropolitan Area of Finland. Renewable energy 99: 813-824.

Kahouli B (2018) The causality link between energy electricity consumption, CO2 emissions, R\&D stocks and economic growth in Mediterranean countries (MCs). Energy 145: 388-399.

Khalil HB and Zaidi SJH (2014) Energy crisis and potential of solar energy in Pakistan. Renewable and Sustainable Energy Reviews 31: 194-201.

Khare V, Nema S and Baredar P (2013) Status of solar wind renewable energy in India. Renewable and Sustainable Energy Reviews 27: 1-10.

Khuong PM, McKenna R and Fichtner W (2019) Analyzing drivers of renewable energy development in Southeast Asia countries with correlation and decomposition methods. Journal of cleaner production, 213: 710-722.

Kumar M, Reddy KS, Adake RV, et al. (2015) Solar powered micro-irrigation system for small holders of dryland agriculture in India. Agricultural Water Management 158: 112-119.

Le TH and Nguyen CP (2019) Is energy security a driver for economic growth? Evidence from a global sample. Energy policy 129: 436-451.

Lin B and Ahmad I (2016) Technical change, inter-factor and inter-fuel substitution possibilities in Pakistan: a trans-log production function approach. Journal of cleaner production 126: 537-549.

Lin B and Raza M (2019a) Analysis of energy related CO2 emissions in Pakistan. Journal of Cleaner Production 219: 981-993.

Lin B and Raza M (2019b) Energy substitution effect on transport sector of Pakistan: a trans-log production function approach. Journal of Cleaner Production: 119606.

Martchamadol J and Kumar S (2012) Thailand's energy security indicators. Renewable and Sustainable Energy 
Reviews 16(8): 6103-6122.

Masud J (2009) Clean energy development in Pakistan. In: 2009. ADB Climate Change and Energy Workshop. Ministry of Finance G of P (2018) Pakistan Economic Survey 2017-2018. Ministry of Finance, Government of Pakistan. Islamabad. Available at: http://www.finance.gov.pk/survey/chapters_18/Pakistan_ES_2017_18_pdf.

Mirza UK, Ahmad N, Harijan K, et al. (2009) Identifying and addressing barriers to renewable energy development in Pakistan. Renewable and Sustainable Energy Reviews 13(4): 927-931.

Morita K and Matsumoto KI (2018) Synergies among climate change and biodiversity conservation measures and policies in the forest sector: A case study of Southeast Asian countries. Forest Policy and Economics 87: 59-69.

Nasreen S, Anwar S and Ozturk I (2017) Financial stability, energy consumption and environmental quality: Evidence from South Asian economies. Renewable and Sustainable Energy Reviews 67: 1105-1122.

Nawaz SMN and Alvi S (2018) Energy security for socio-economic and environmental sustainability in Pakistan. Heliyon 4(10): e00854.

NCCP (2012) National Climate Change Policy (NCCP). Government of Pakistan - Ministry of Climate Change Islamabad,Pakistan. Available at: http://www.gcisc.org.pk/National_Climate_Change_Policy_2012.pdf.

Niu S, Li Z, Qiu X, et al. (2019) Measurement of effective energy consumption in China's rural household sector and policy implication. Energy policy 128: 553-564.

Owusu PA and Asumadu-Sarkodie S (2016) Is there a causal effect between agricultural production and carbon dioxide emissions in Ghana? Environmental Engineering Research 22(1): 40-54.

Pakistan Today (2018) Pakistan Circular Debt. Available at: https://www.pakistantoday.com.pk/2018/09/28/powerdivision-circular-debt-soars-to-rs1300bn/.

Pasha H, Ghaus-Pasha A and Saleem W (2013) Economic Costs of Load Shedding in Pakistan. Pakistan: Institute of Public Policy, Beaconhouse National University (BNU).

Peters GP, Andrew RM, Canadell JG, et al. (2017) Key indicators to track current progress and future ambition of the Paris Agreement. Nature Climate Change 7(2): 118.

PPIB (2002) Policy for Power Generation Projects. Government of Pakistan. Available at: http://www.ppib.gov.pk/PowerPolicy2002.pdf.

Quirapas MAJR, Lin H, Abundo MLS, et al. (2015) Ocean renewable energy in Southeast Asia: a review. Renewable and Sustainable Energy Reviews 41: 799-817.

Raza MY and Shah MTS (2019) Analysis of coal-related energy consumption in Pakistan: an alternative energy resource to fuel economic development. Environment, Development and Sustainability: 1-22.

Raza MY, Wasim M and Sarwar MS (2019) Development of Renewable Energy Technologies in rural areas of Pakistan. Energy Sources, Part A: Recovery, Utilization, and Environmental Effects: 1-21.

REN21 (2017). Available at: http://www.ren21.net/wp-content/uploads/2017/06/17 8399_GSR_2017_Full_Report_0621_Opt.pdf.

Sadiq M (2018) Solar water heating system for residential consumers of Islamabad, Pakistan: A cost benefit analysis. Journal of cleaner production 172: 2443-2453.

Salarizadeh P, Askari MB, Seifi M, et al. (2019) MoS2 coating on different carbonaceous materials: Comparison of electrochemical properties and hydrogen evolution reaction performance. Journal of Electroanalytical Chemistry: 113198.

SDPI (2014) Pakistan Energy Vision - $2035 . \quad$ Available at: https://sdpi.org/publications/files/Pakistan\%20Energy\%202035-FINAL\%2020th\%20October\%202014.pdf.

Şen Z (2004) Solar energy in progress and future research trends. Progress in energy and combustion science 30(4): $367-416$.

Shaikh F, Ji Q and Fan Y (2015) The diagnosis of an electricity crisis and alternative energy development in Pakistan. Renewable and Sustainable Energy Reviews 52: 1172-1185.

Shakeel SR, Takala J and Shakeel W (2016) Renewable energy sources in power generation in Pakistan. 
Renewable and Sustainable Energy Reviews 64: 421-434.

Shakya SR and Shrestha RM (2011) Transport sector electrification in a hydropower resource rich developing country: Energy security, environmental and climate change co-benefits. Energy for Sustainable Development 15(2): 147-159.

Shi L, Qi S, Qu J, et al. (2019) Integration of hydrogenation and dehydrogenation based on dibenzyltoluene as liquid organic hydrogen energy carrier. International Journal of Hydrogen Energy 44(11): 5345-5354.

Shrestha RM and Shakya SR (2012) Benefits of low carbon development in a developing country: Case of Nepal. Energy Economics 34: S503-S512.

Song Y, Zhang M and Sun R (2019) Using a new aggregated indicator to evaluate China's energy security. Energy Policy 132: 167-174.

Sovacool BK (2017) Contestation, contingency, and justice in the Nordic low-carbon energy transition. Energy Policy 102: 569-582.

Stritih U, Zupan G and Butala V (2007) Review of green electricity production in Slovenia. Renewable and Sustainable Energy Reviews 11(9): 2201-2208.

Sustainable Development (2017) High-Level Political Forum. Malaysia SDG 2017 Recommend for Governance. Government of Malaysia. Available at: https://sustainabledevelopment.un.org/hlpf/2017.

Terziotti LT, Sweet ML and Jr JTM (2012) Modeling seasonal solar thermal energy storage in a large urban residential building using TRNSYS 16. Energy and buildings 45: 28-31.

Tongsopit S, Chaitusaney S, Limmanee A, et al. (2015) Scaling Up Solar PV: A Roadmap for Thailand. Energy Research Institute, Chulalongkorn University.

Wei H, Liu J and Yang B (2014) Cost-benefit comparison between Domestic Solar Water Heater (DSHW) and Building Integrated Photovoltaic (BIPV) systems for households in urban China. Applied energy 126: 4755.

World Bank (2016) Regulatory Indicators for Sustainable Energy. Available at: http://www.worldbank.org/en/topic/energy/publication/rise — regulatory-indicators-for-sustainable-energy.

Xu H, Liu J, Qin D, et al. (2013) Feasibility analysis of solar irrigation system for pastures conservation in a demonstration area in Inner Mongolia. Applied energy 112: 697-702.

Yao L and Chang Y (2014) Energy security in China: a quantitative analysis and policy implications. Energy Policy 67: 595-604.

Yatim P, Mamat MN, Mohamad-Zailani SH, et al. (2016) Energy policy shifts towards sustainable energy future for Malaysia. Clean Technologies and Environmental Policy 18(6): 1685-1695.

Zhang C, Romagnoli A, Kim JY, et al. (2017) Implementation of industrial waste heat to power in Southeast Asia: an outlook from the perspective of market potentials, opportunities and success catalysts. Energy Policy 106: 525-535. 